\title{
HISTORICAL ASSOCIATION MEETING
}

The convention of the Mississippi Valley Historical Association for this year was held in Cedar Rapids April $22-23,1943$. The program was filled with interesting addresses and discussions, covering a wide range of historical topics, presented by able students of history from many colleges and universities, and the attendance was excellent. The association was formed with the advice and assistance of Edgar R. Harlan, former curator of the Iowa State Department of History and Archives, and at the close of the Cedar Rapids meeting, Prof. Louis B. Schmidt, of the Iowa State college, paid brief tribute to Mr. Harlan as follows:

Edgar Rubey Harlan devoted thirty years of his life to the cause of building for his beloved state of Iowa the State Historical Department. This department has more recently been designated officially as the Iowa State Department of History and Archives.

The founder of the department was Charles Aldrich who appointed Harlan as his assistant. Aldrich was succeeded by Harlan as curator in 1908. This position he held until his retirement in 1937.

The department had a modest beginning in the Aldrich collection of manuscripts and autographs which Harlan built up by the addition of books, newspapers, manuscripts, historical paintings, and materials relating to the early fauna and flora of Iowa and to the geology of the state

Indian life and Indian culture later became Harlan's chief hobby. He obtained through his friendship with the Sac and Fox Indians in Iowa a valuable collection of materials relating to the customs and the lore and the language of these tribes.

Mr. Harlan built up the Archives division and the rare collections of state documents which are of great historical interest and value. He also took an active interest in the marking of historic spots and trails in Iowa and in the Iowa State park movement.

The Iowa State Department of History and Archives is largely Harlan's title to an enduring place in Iowa history. It is a credit to him and to the state which he served so loyally and so successfully.

We pay tribute to Mr. Harlan, not only for his distinguished service as curator of this agency for the collection and preservation of the materials of history, but also for his interest and activity in the promotion of the Mississippi Valley Historical Association of which he was one of the founders and charter members and at one time also its president. 
Copyright of Annals of Iowa is the property of State of Iowa, by \& through the State Historical Society of Iowa and its content may not be copied or emailed to multiple sites or posted to a listserv without the copyright holder's express written permission. However, users may print, download, or email articles for individual use. 